\title{
Efficiency and Effectiveness of C2C Interactions and Mutual Learning for Value Co-Creation: Agent-Based Simulation Approach
}

\author{
Santi Novani ${ }^{1} \&$ Kyoichi Kijima ${ }^{2}$ \\ ${ }^{1}$ School of Business and Management, Bandung Institute of Technology, Indonesia \\ ${ }^{2}$ Department of Value and Decision Science, Tokyo Institute of Technology, Japan \\ Correspondence: Santi Novani, School of Business and Management, Bandung Institute of Technology. \\ Indonesia. E-mail: snovani@sbm-itb.ac.id, kijima@valdes.titech.ac.jp
}

Received: February 28, 2013

Accepted: March 15, 2013

Online Published: April 14, 2013

doi:10.5539/ijbm.v8n9p50

URL: http://dx.doi.org/10.5539/ijbm.v8n9p50

\begin{abstract}
The active role of customers and their experience to create the value in service system have been recognized in the literature. So far, the focus of value co-creation only for business-business (B2B) or business-customers (B2C), meanwhile the attention to the customer-to-customer $(\mathrm{C} 2 \mathrm{C})$ is not so much. Recently, the attention to $\mathrm{C} 2 \mathrm{C}$ interaction is increasingly viewed by marketer and researcher. However, the existing research of $\mathrm{C} 2 \mathrm{C}$ is on the conceptual and empirical model, therefore it may not describe $\mathrm{C} 2 \mathrm{C}$ interaction dynamically. In this research, we show and develop a model of customers' interaction by using agent-based simulation to capture the dynamic of interaction. The research aim is to explore how effective and efficient $\mathrm{C} 2 \mathrm{C}$ by engaging customers' experience in value co-creation. Furthermore, we investigate the needs of mutual learning by using agent based simulation. The previous research is focus on two types of $\mathrm{C} 2 \mathrm{C}$ interaction, i.e., face-to-face and social media interaction. In the present research, we show more general the needs of human interaction by engaging customers' experience which compare between 'customer-to-customer $(\mathrm{C} 2 \mathrm{C})$ interaction' and 'no interaction' (i.e., customers interact with the provider directly without interaction with other customers). By conducting agent based simulation, we investigate how $\mathrm{C} 2 \mathrm{C}$ interaction is effective which measured by learning performance and how efficient which measured by learning efficiency. On the other hand, we conduct sensitivity analysis to investigate the needs of mutual learning between customers and provider in value co-creation. In our simulation result, it shows customer-to-customer $(\mathrm{C} 2 \mathrm{C})$ interaction gives significant influence than 'no interaction'. Moreover, we have already shown the needs mutual learning between customers and provider from the simulation results.
\end{abstract}

Keywords: efficient, effective, mutual learning, no interaction, customer-to-customer (C2C) interaction

\section{Introduction}

Driving the paradigm shift from exchange to value creation (Sheth and Uslay, 2007), service dominant logic (S-D logic) undertake to move marketing thinking away from G-D logic (Vargo and Lusch, 2004; Lusch and Vargo, 2006d; Vargo \& Lusch, 2008c). S-D logic is a mindset proposing that service exchange is basic concern of organizations, markets, and society (Cova, Ford, \& Salle, 2008; Alter, 2010). S-D logic is a new perspective to guide theory of marketing and practice (Vargo \& Lusch, 2006a; Lusch \& Vargo, 2008; Vargo and Lusch, 2008b; Maglio, Vargo, Caswell \& Spohrer, 2009), also view of value creation. Eight foundational premises (FPs) were originally developed, forming the basis of S-D logic.

Based on S-D logic, customers as a co-creator of value and them fundamentally changing the dynamics of the marketplace. There are many well-recognized linkages in the business-customers (B2C) relationships, but another linkage that is important, i.e., customer-to-customer (C2C) relationship is insufficiently studied (Martin, 1996). As Gummesson observes, the growing area of research and application is on the active role of customers and $\mathrm{C} 2 \mathrm{C}$ interaction in value co-creation.

The attention to the $\mathrm{C} 2 \mathrm{C}$ interaction would be as useful as attention to the business-business (B2B) relations or business-customers (B2C) relations (Pranter \& Martin, 1991). For example, in the hotel, customers and receptionist are in direct contact, face-to-face or computer mediated. Perceptions formed by the customers about service provider's service to create a service experience. Customers can share their perception of experience to the others which defined as customer-to-customer interaction (C2C). 
C2C markets are creatives to allow customers to interact with the others. For example, in airline service, customers can browse message by using social media site or sharing their experience about air travel with the others which all refer to the $\mathrm{C} 2 \mathrm{C}$ interaction.

We have developed a model of $\mathrm{C} 2 \mathrm{C}$ interaction which focuses on two communication styles, i.e., face-to-face and social media interaction (Novani \& Kijima, 2012). In the present research, we show more general the needs of human interaction by engaging customers' experience. The research aim is to investigate how $\mathrm{C} 2 \mathrm{C}$ interaction is effective by learning performance and how efficient by learning efficiency.

We compare between 'customer-to-customer (C2C) interaction' and 'no interaction' (i.e., customers interact with the provider directly without interaction with other customers) by conducting agent based simulation.

\subsection{The Needs of Customer-to-Customer (C2C) Interaction}

Nowadays customers are connected in many ways, including social media such as social networking sites, Facebook, Twitter, blogs or online community (Thurau, 2010; Wuyts, 2010). Under this new environment, provider understands to reconsider the need of $\mathrm{C} 2 \mathrm{C}$ interactions. Based on the literature, research which considered on C2C interaction is still limited (Parker \& Ward, 2000). Martin (1996) argued the customers' consideration to the business is impressed by the quality of C2C relations (Martin, 1996; Zeithaml, 1981), the customers' adaptation or reversion (Martin \& Pranter, 1989), and customers' tendency to spread the information By using WOM and influence the others.

Thus, research on the $\mathrm{C} 2 \mathrm{C}$ interaction allows examining the active role of customers to create the value not only with provider but also among customers itself. Recently, research on $\mathrm{C} 2 \mathrm{C}$ interaction is recognized important in service research as in social dimensions (Baker, 1987). There are contributions which include case studies such as in hospital which portraying $\mathrm{C} 2 \mathrm{C}$ as a main source of value co-creation.

Customers actively browse information from the others by using the contact via face-to-face or the latest technology (social media) on what hotel to stay, which airline to fly on and so on. In this research, we show more the needs of $\mathrm{C} 2 \mathrm{C}$ by engaging customers' experience to investigate how effective and how efficient is $\mathrm{C} 2 \mathrm{C}$ by conducting agent-based simulation.

\subsection{Research Question and Hypothesis}

In this research, the group of decision is modeled as hypergame between customers and provider in the value co-creation. We measure effectiveness by learning performance and efficient by learning efficiency.

For this simulation, we propose two research questions, these are:

1) Research question 1: How to investigate that $\mathrm{C} 2 \mathrm{C}$ interaction gives impact on value co-creation depending on learning performance?

2) Research question 2: How to investigate that $\mathrm{C} 2 \mathrm{C}$ interaction gives impact on value co-creation depending on learning efficiency?

According to those research questions, we have two hypotheses as follows:

1) Hypothesis 1: Customer-to-customer $(\mathrm{C} 2 \mathrm{C})$ interaction is better than 'no interaction' which based on the learning performance.

2) Hypothesis 2: Customer-to-customer (C2C) interaction is better than 'no interaction' which based on the learning efficiency.

\section{Method}

This research proposes a method of agent based simulation in terms of the adaptive learning model of hypergame. Hypergame is used to describe sharing the internal model as a value and mutual understanding among entities in the service system process, i.e., customers and provider.

On the other hand, agent-based simulation in terms of the adaptive learning model is used to illustrate how customers are interacting with each other. They will learn to get information about the providers by interaction dynamically. It allows us to formulate how customers and providers revise current internal models, according to their experiences so far, select actions and change their internal models.

\subsection{Modeling of Customers' Interaction and Provider: Hypergame Analysis}

In this part we adopt hypergame analysis to represent a value as internal model among entities in the service system, i.e., customers and provider (Bennet, et. al, 1989) as already proposed by previous paper. Let us denote a set of customers, a learning group, by $C=\{1,2,3, \ldots, n\}$ and a set of providers $P=\{1,2\}$. Our example of Airline 
service selection problem can be formulated as a simple hypergame involving two types of players, customer $i \in C$ and provider $j \in P$.

Definition 1. A simple hypergame with the customer $i$ and provider $j$ is a pair $\left(G_{i}, G_{j}\right)$ where $G_{i}=\left(S_{i}, S_{j i}, \geq_{i}, \geq_{j i}\right)$ is a game that $i$ believes to play, while $G_{j}=\left(s_{j}, S_{i j}, \geq_{j}, \geq_{i j}\right)$ is a game that $j$ believes to play.

In $G_{i}, S_{i}$ represents a set of strategies for customers $i$, while $S_{j i}$ representing a set of strategies which customer $i$ assumes that provider $j$ can set up $z_{i}$ Represents customer $i^{\prime} s$ preference ordering on $S_{i} \times S_{j i}$, while $\geq_{j i}$ is a preference ordering on $S_{i} \times S_{j i}$ which customer $i$ assumes that provider $j$ holds. We define $G_{j}$ similarly. We assumed every preference is linear orderings and it's represented by an ordinal utility function $\pi$.

\subsubsection{Assumption of Hypergame Analysis for Customers}

First, we put the following assumptions for each customer $i \in C$ :

- $\quad i$ is associated with subjective game $G_{i}$. These internal models are in general different from each other.

- $i$ has three strategies about the level of expectation, that is high $(H)$, middle $(M)$ and low expectation $(L)$.

- $\quad i$ knows the set of strategies of provider $j$ about the level of service orientation, i.e., high service orientation $(H)$ and low service orientation $(L)$.

- The outcome preference for customer $i \in C$ is expressed by an ordinal utility function $\pi_{i}: S_{i} \times S_{j_{i}} \rightarrow\left\{1,2,3, \ldots,\left|S_{i}\right| \times\left|S_{j i}\right|\right\}$.

- $\quad i$ believes provider $j$ 's ordinal utility function is $\pi_{j i}: S_{i} \times S_{j_{i}} \rightarrow\left\{1,2,3, \ldots,\left|S_{i}\right| \times\left|S_{j i}\right|\right\}$.

We represent the customer i's internal model as follows:

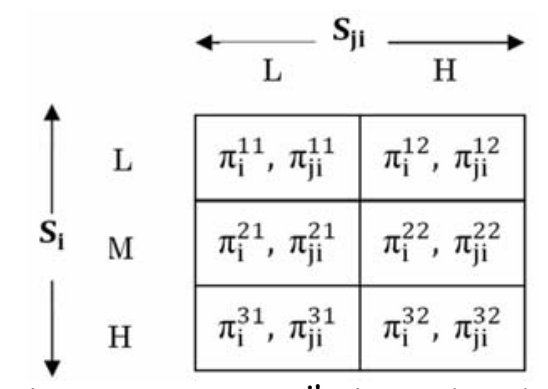

Figure 1. Customer i's internal model

In this research, we investigate how effective and efficient of $\mathrm{C} 2 \mathrm{C}$ interaction which compared with 'no interaction'. Therefore, we define 'no interaction' and $\mathrm{C} 2 \mathrm{C}$ interaction as follows:

\section{1) No Interaction (Customer-Provider).}

This type of customers interact the provider directly without interaction among customers. We refer to the customer-provider interaction.

\section{2) Customer-to-Customer (C2C) Interaction (Customer-Customer).}

This type of customers interacts with other customers in the larger society and asking unanimous people for opinions about the provider. We refer to the customer-to-customer $(\mathrm{C} 2 \mathrm{C})$ interaction.

\subsubsection{Assumption of Hypergame Analysis for Provider: In-Depth Interview}

We use in-depth interviewing as the main method to collect the data for the study which adopted as an interpretative approach. The central concern of the interpretative research is to understand human experiences at a holistic level. To investigate Airline service selection problem in Indonesia, we choose Garuda Indonesia, since this airline lead the best service quality in Indonesia. The purpose is to derive an internal model from the provider's perspective.

Based on this, they perceive customers have three strategies based on his/her expectation. Garuda Indonesia believes that he/she can offer two service contents, i.e., high and low service content. When customers comes to service, their expectation can get a little fuzzy. Customers do not know what strategy that he/she will play. We categorized the customers' strategy based on the expectation as follows: 
3) Low expectation (L).

It defines as customers' expectation which remarkably straightforward and takes it for granted. For example, we expect the airline to be able to take off, fly to a destination and land safely.

4) Middle expectation (M).

It defines as customers' expectation which required form of satisfaction. For example, we expect to treat warmly by airline crew and all requirements are satisfied.

5) High expectation $(\mathrm{H})$.

It defines as customers' expectation which requires some delights or a service that is so plentiful which it fascinates customers. For example, Airline gives passengers a superior quality service that received for executive class only for all customers.

Based on the interview, we recognize Garuda offer two types of service contents, that is:

6) Low service content (L).

A service which defines as a content offered by low-cost carrier (LCC), such as not includes an entertainment or meal.

7) High service content $(\mathrm{H})$.

A service which define as a full service which includes a good quality of service and comfort.

If we formulate these strategies into hypergame analysis, then the provider, Garuda Indonesia ( $\mathrm{g}$ ), believes that customers (c) have three expectation levels, i.e., low (L), middle (M) and high expectation (H). We denote $S_{c g}$ as a customers' strategy set which perceived by provider. On the other hand, we also describe the provider has two strategies, i.e., high-content service $(\mathrm{H})$ and price-content service $(\mathrm{L})$. We denote $\mathrm{s}_{\mathrm{g}}$ as a strategy set of provider. Figure 2 shows Garuda Indonesia's internal model as a high-oriented service provider.

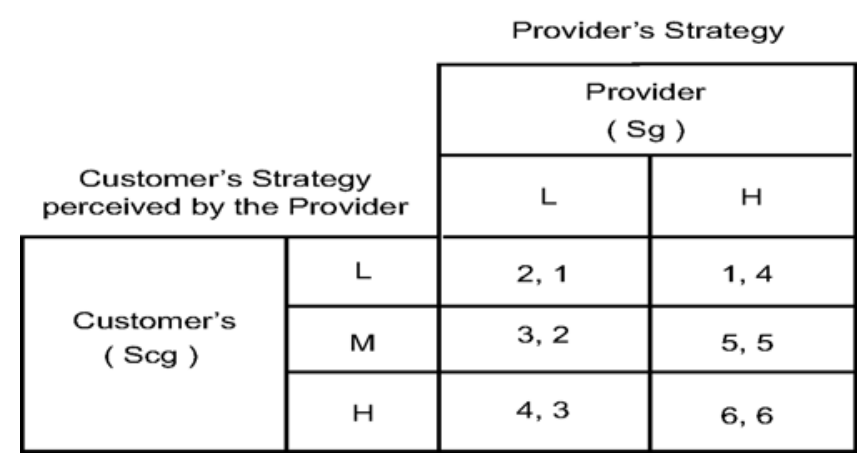

Figure 2. Provider's internal model

\subsection{Agent Based Simulation: An Adaptive Learning Model of Hypergame}

In this part, we develop an adaptive learning model of hypergame which support the customers to learn and share their experience of interaction. The adaptive learning model of hypergame in the service system is portrayed by figure 3 . 


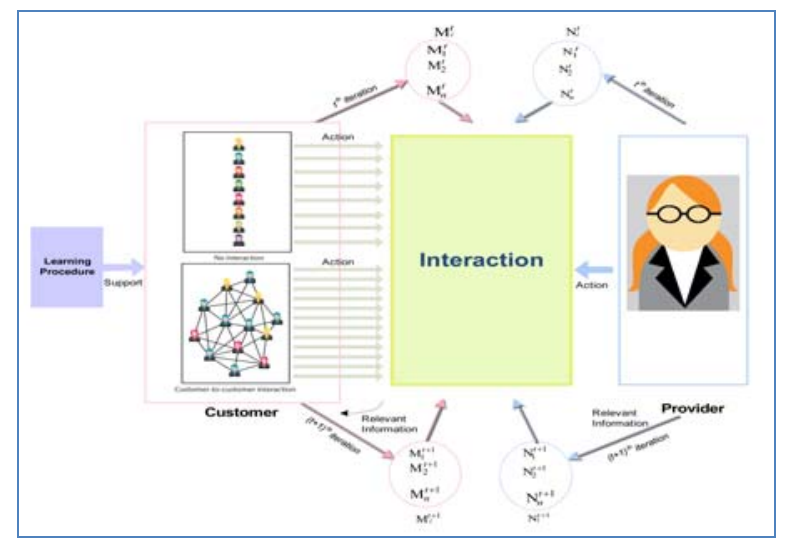

Figure 3. Adaptive learning model of hypergame of customers and provider in the service system

From the figure, we categorized customers into two styles, i.e., 'no interaction' and customer-to-customer (C2C) interaction. We use the learning procedure and the adaptation process of customers based on the previous paper (Novani and Kijima, 2012). Customers have actively revised the current internal model after they get the information repetitively. In this part, we propose learning procedure in more detail.

\subsubsection{Learning Procedure}

In this part, we will illustrate a learning procedure (Figure 4).

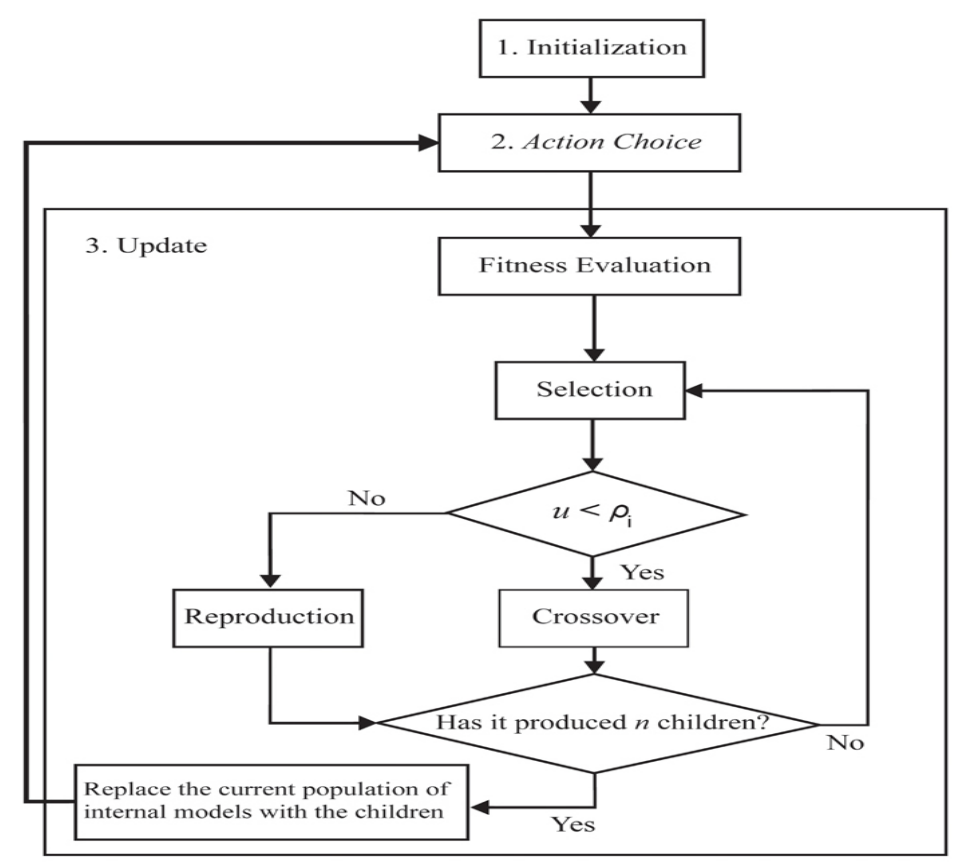

Figure 4. Learning procedures activities (Putro, 2009)

The learning procedure consists of the following three stages:

1) Stage 1: Initialization

In this stage, the internal model is generated randomly and each internal model is encoded as a chromosome.

(a) Generation of initial population

We generate the internal model which depend on the communication style as follows:

- No interaction.

We generate randomly internal models of customers. In this type, customers directly communicate with the 
provider.

- Customer-to-Customer (C2C) interaction.

We generate randomly internal models of customers in the larger society. In this type, customers communicate with other customers before they interact with the provider.

(b) Encoding

We encode customers' value (internal model) as a chromosome. Chromosome of customer $i \in C$ is defined as follows:

Assume $M_{i}$ is an internal model of $i$.

Let us denote by $\pi_{i}^{m k}$ the $(m, k)$ cell of the internal model.

Let us denote by $\pi_{j i}^{m k}$ the $(m, k)$ cell of the internal model.

In this research, we have $m=3$, for the level of customers' expectation and $k=2$ for the level of service orientation. $M_{i}$ is represented by Figure 5 .

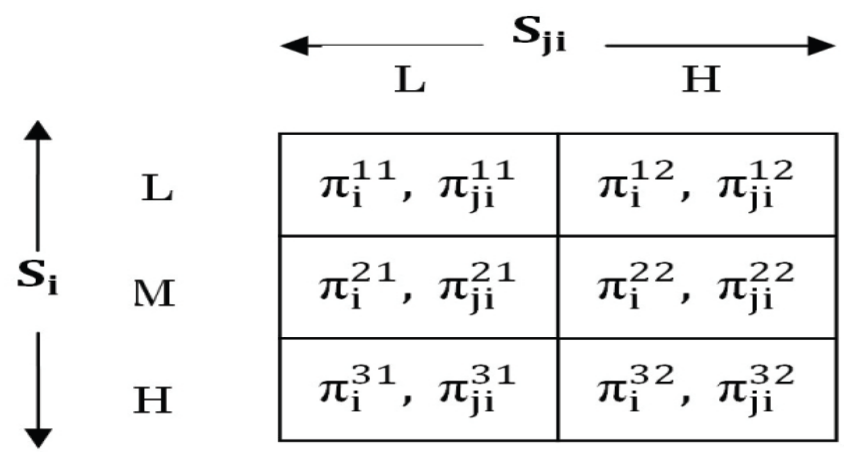

Figure 5. General representation of $M_{i}$

By taking the values on the left hand side of $M_{i}$, we have Figure 6, from which we define a chromosome shown by Figure 7 .

\begin{tabular}{|c|c|c|}
\hline & L & $\mathbf{H}$ \\
\hline L & $\pi_{i}^{11}$ & $\pi_{i}^{12}$ \\
\hline $\mathrm{M}$ & $\pi_{\mathbf{i}}^{21}$ & $\pi_{i}^{22}$ \\
\hline $\mathbf{H}$ & $\pi_{i}^{31}$ & $\pi_{i}^{32}$ \\
\hline
\end{tabular}

Figure 6. Internal model of customer $i$ (left hand side)

$$
\begin{array}{lcc}
\pi_{i}^{11} \pi_{i}^{12} & \pi_{i}^{21} \pi_{i}^{22} & \pi_{i}^{31} \pi_{i}^{32} \\
\text { the } 1^{\text {st }} \text { row } & \text { the 2 } 2^{\text {nd }} \text { row } & \text { the } 3^{\text {rd row }}
\end{array}
$$

Figure 7. Representation of chromosome for customer $i$ (left hand side)

We can define the right hand side chromosome from Figure 6 in a similar way. For example, we represent a customers' internal model as portrayed by Figure 8 . 


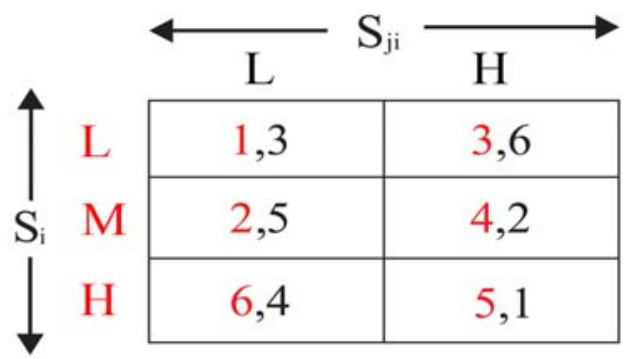

Figure 8. Example of an initial internal model of customer $i$

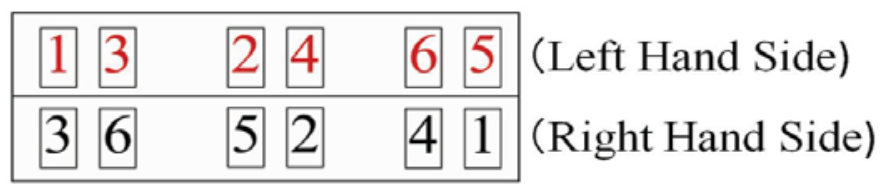

Figure 9. Example of representation customer's chromosome (1st row) and provider based on customers' perception (2nd row)

From the internal model, we can encode chromosome of customers i by Figure 9. We encode the chromosome of provider $j$ similarly.

2) Stage 2: Action Choice

We use action choice which based on decision rules, i.e., subjective Nash Equilibrium $\left(N_{i}\right)$ and random action. The procedures are followed:

(i) If $N_{i}=\phi, i \in C$ chooses an action from $S_{i}$ randomly.

(ii) If $N_{i}=\left\{\left(i_{k}^{*}, j_{m}^{*}\right)\right\}, i \in C$ chooses $i_{k}^{*}$ as his/her action.

(iii) If $\left|N_{i}\right|>1, i \in C$ selects randomly a subjective Nash Equilibrium from $N_{i}$.

3) Stage 3: Update

Each customer revises the current population of internal models by genetic algorithm as follows:

Fitness Evaluation ( Fit (i) )

The fitness function is to give a meaningful, measurable, and comparable value given a set of genes. Fitness evaluation implies how customers $i$ calculate the fitness score by using a fitness function that maps his/her perception into $[0,1]$.

We calculate the fitness score as follows:

Let us define CE1 by CE2 $=$ absolute value $\left(\pi_{i}^{m k}-\pi_{j i}^{m k}\right)$

CE1 represents a cost of perception, i.e., cost incurred to change current perception about the provider's outcome $\pi_{i}^{m k}$ of the current outcome of customers $\pi_{j i}^{m k}$.

Let us define CE2 by $C E 2=$ absolute value $\left(\pi_{i}^{m k}-\left|S_{i}\right| \times\left|S_{j i}\right|\right)$

CE2 represents a cost of exchange incurring maximum payoff, i.e., cost needed to change the current outcome of customers $\pi_{i}^{m k}$ to the maximum $\left|S_{i}\right| \times\left|S_{j i}\right|$ current perception of the highest outcome possibly achieved by provider.

Let us define CE3 by $C E 3=$ absolute value $\left(\pi_{i}^{m k}-\pi_{j}^{m k}\right)$

CE3 represents a cost of mutual learning (understanding) between customers on current outcome $\pi_{i}^{m k}$ and provider on current outcome $\pi_{j}^{m k}$.

We define $\mathrm{CE}$ as the total of CE1, CE2 and CE3, that is $C E=C E 1+C E 2+C E 3$

Then, the fitness Fit ( $i$ ) is defined by: 


$$
\text { Fit }(i)=\frac{1}{(C E)+1}
$$

Then, if CE is zero then there is no difference between the perception and information which received by customers from the providers game. It means the fitness score achieves the highest value, i.e., 1. Breeding Process Selection. In the selection process, we choose an internal model by using a roulette wheel method which based on the fitness score ratio (Ratio Fit(i)) as follows:

Let Fit(i) be the fitness score of $i$ 's internal models, then calculate Ratio Fit (i) $=\frac{\text { Fit (i) }}{\sum_{k=1}^{n} \text { Fit }(k)}$, for $i \in C$.

Let Rand be a random number between 0 and 1, then $i$ selects an internal model as a parent if $\sum_{k=1}^{j}$ Ratio Fit(i) $\geq$ Rand .

Otherwise, the internal model will not be selected as a parent.

Therefore, selection implies that all customers in $C$ share their current internal models and their fitness scores.

Crossover:

After doing selection, each customer begins to create an internal model by crossover or reproduction which depends on crossover probability $\rho_{i}$. We determine $\rho_{i}$ by a pre-simulation. The mechanism that decides whether a pair of customers will adopt crossover or reproduction is described as follows:

Let $\rho_{i}$ be a crossover probability, and we generate a random number $\mu$ from Uniform $(0,1)$ distribution. The procedure consists of the following conditions:

If $\mu<\rho_{i}$, then do crossover.

We produce two new internal models by mating the parents. The chromosome probability $\rho_{i}$ is determined by pre-simulation results.

Otherwise, do reproduction. We simply copy the parent to produce two children.

We use "one point crossover" method, and change it for our purpose. Crossover in this paper means to combine the parents and to revise chromosomes. The procedure of crossover as follows:

Step 1: (Figure 10)

Select a cut point $b_{k} \in\left|S_{i}\right| \times\left|S_{j i}\right|$.

Let $C_{p}$ and $C_{q}$ be chromosomes.

Check the cut point position from the chromosome $C_{p}$ and $C_{q}$ as follows:

If $b_{k}{ }^{\text {th }}$ position of $C_{p}$ is not equal to $b_{k}^{\text {th }}$ the position of $C_{q}$, then change chromosome from the cut point until the end.

If $b_{k}{ }^{\text {th }}$ position of $C_{p}$ is equal to $b_{k}^{\text {th }}$ the position of $C_{q}$, then do not change.

Step 2: (Figure 10).

Revise the chromosome in such a way that there is no duplication of genes in the chromosome. 


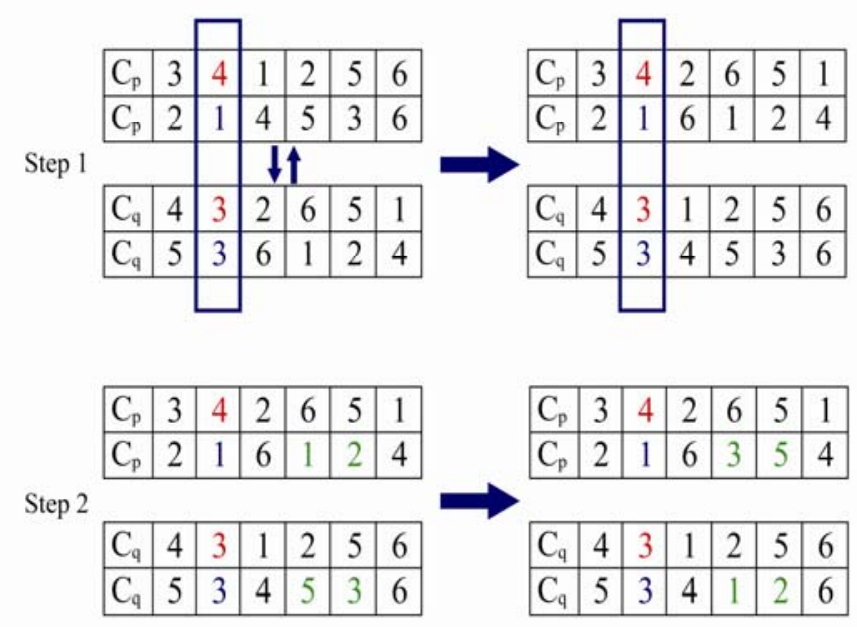

Figure 10. Chromosome combination illustration

\section{Breaking Rule}

If the maximum iteration is reached or the fitness value gets equal to 1 then the simulation run will be stop. It means, if the highest performance or maximum iteration is achieved, the update process of genetic algorithm will not be able to produce new internal models.

\subsubsection{Parameters}

In this part we use the parameters which based on the pre-simulation and it portrayed by following table.

Table 1. Definition of parameters

\begin{tabular}{ll}
\hline Parameters & Numbers \\
\hline Number of customer of no interaction & 1000 \\
Number of customers of C2C interaction & 1000 \\
Maximum generation number & 100 \\
Maximum runs number & 100 \\
Probability of crossover & 0.7 \\
\hline
\end{tabular}

\section{Results}

We now investigate how effective of $\mathrm{C} 2 \mathrm{C}$ interaction which measured by learning performance from the simulation results.

\subsection{Hypothesis 1: Learning Performance}

1) Scenario 1.

In this scenario, we include only two costs, i.e., cost of perception and cost of exchange incurring maximum payoff. We do not include cost of mutual learning among customers and provider to create the value. 


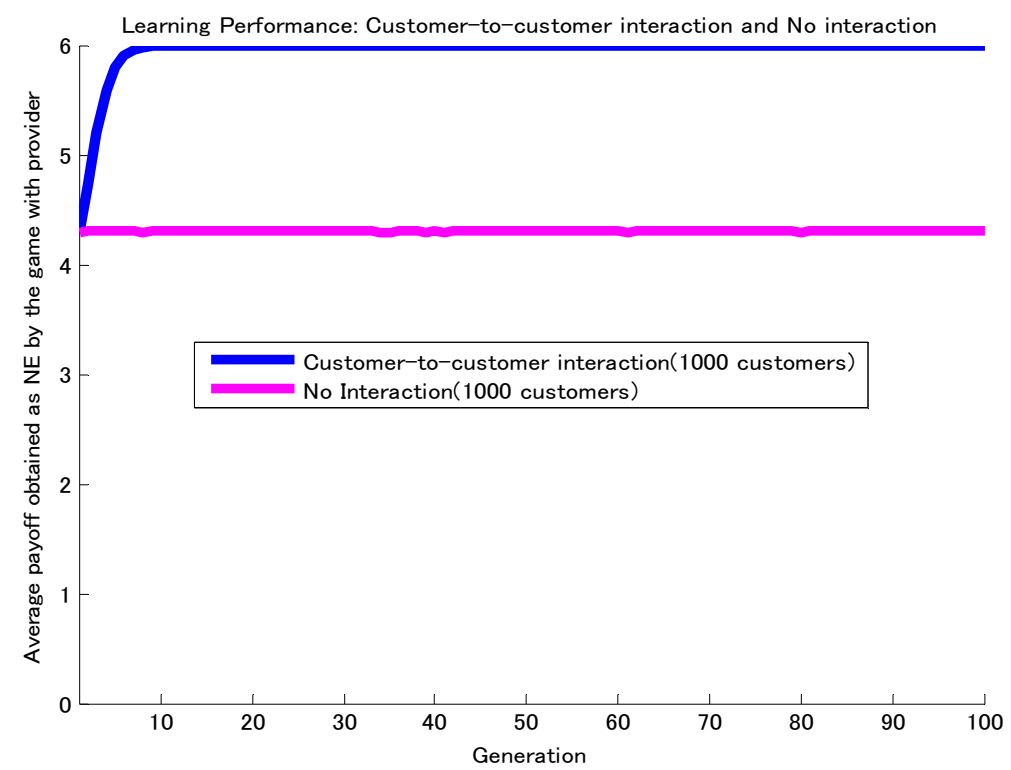

Figure 11. Learning performance of 'no interaction' vs C2C interaction in scenario 1

From the simulation result we could claim that 'no interaction' could not meet a good performance than customer-to-customer interaction $(\mathrm{C} 2 \mathrm{C})$. The willingness to communicate and share the internal model between community members is very important to create the value in the service.

2) Scenario 2.

In this scenario, we include total fitness function. It includes cost of perception, cost of exchange incurring maximum payoff and cost of mutual learning. The simulation result is portrayed by figure 12 .

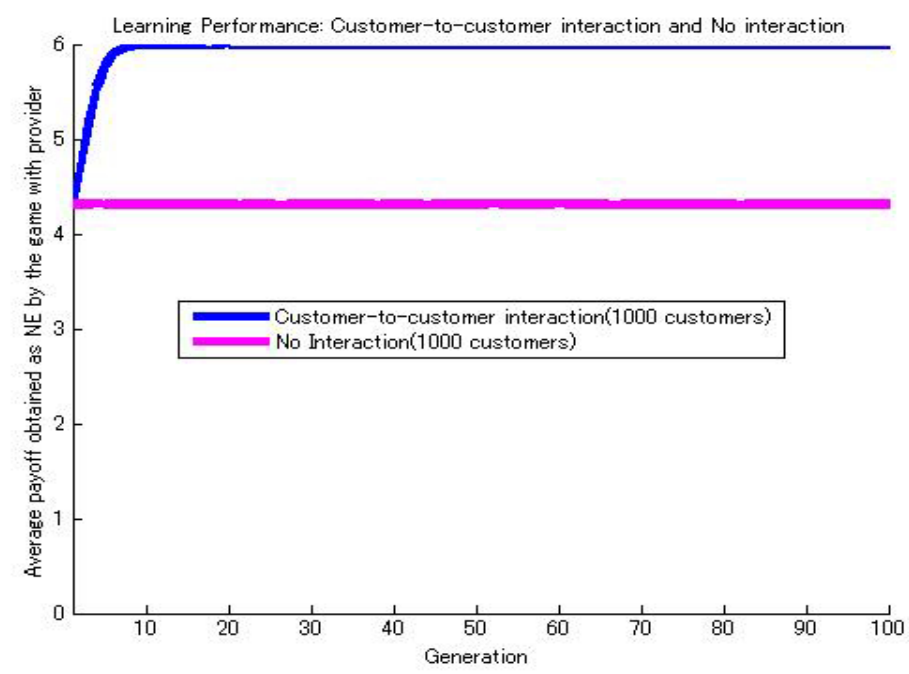

Figure 12. Learning performance of 'no interaction' vs $\mathrm{C} 2 \mathrm{C}$ interaction in scenario 2

From the simulation result, the learning performance of 'no interaction' is the worst one. There are no information exchanges among customers itself; therefore the average payoff seems not change. If there is no interaction, then the learning performance cannot reach the highest result if compared with customer-to-customer $(\mathrm{C} 2 \mathrm{C})$ interaction.

In summary, we could claim that customer-to-customer (C2C) interaction always show a good performance than no interaction. The customer cannot learn about provider since there is no interaction between the customers in their community. It shows the robustness of our simulation is robust since the result is similar. 


\subsection{Hypothesis 2: Learning Efficiency}

We now investigate how $\mathrm{C} 2 \mathrm{C}$ interaction is more efficient by measuring it with learning efficiency.

1) Scenario 1.

First scenario, we include only two costs, i.e., cost of perception and cost of exchange incurring maximum payoff as mentioned before. We now explore the importance customer-to-customer $(\mathrm{C} 2 \mathrm{C})$ interaction based on learning efficiency and the simulation result is portrayed by figure 13 .

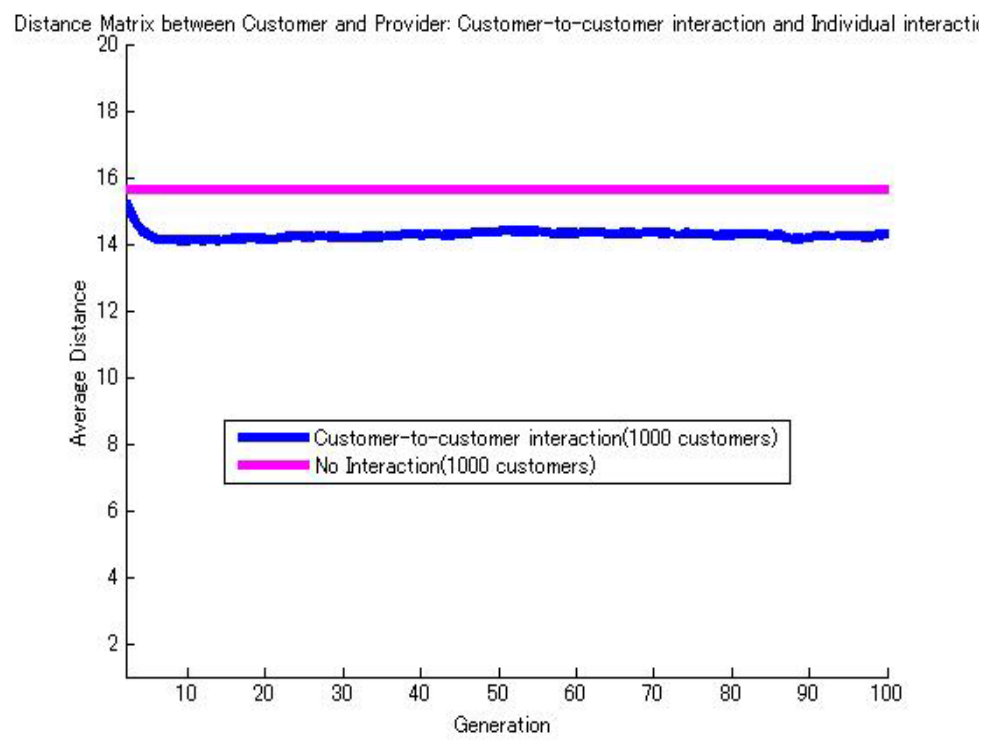

Figure 13. Learning efficiency of 'no interaction' vs C2C interaction in scenario 1

Based on the result, 'no interaction' cannot reach the smallest distance than customer-to-customer (C2C) interaction. The average distance of no interaction is 15.6856 , meanwhile $\mathrm{C} 2 \mathrm{C}$ interaction is 14.2531 . We can claim that mutual learning gives influence as a key facilitator for the efficient sharing the internal model of co-experience and transfer of knowledge from customers.

2) Scenario 2 .

In the second scenario, we include total fitness function. It includes cost of perception, cost of exchange incurring maximum payoff and cost of mutual learning. The simulation result is portrayed by figure 14 .

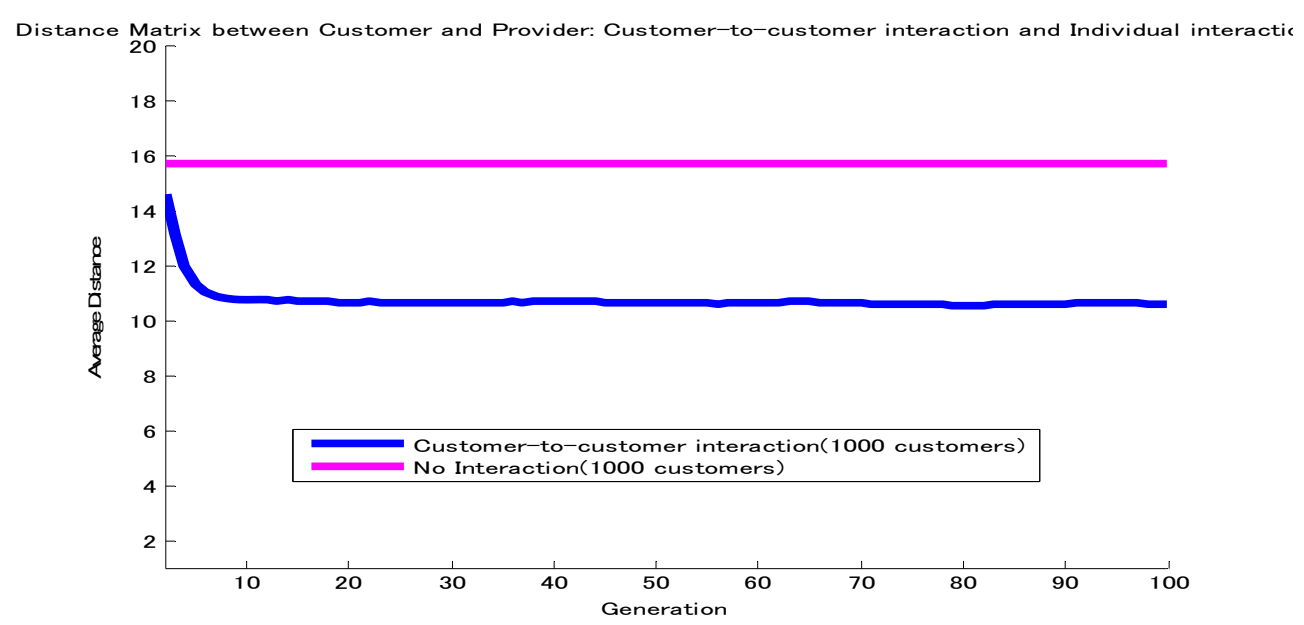

Figure 14. Learning efficiency of 'no interaction' vs $\mathrm{C} 2 \mathrm{C}$ interaction in scenario 2 
From the simulation result, we claim that customer-to-customer $(\mathrm{C} 2 \mathrm{C})$ interaction can reach the smallest distance than no interaction. The average distance of no interaction is 15.6816 and for $\mathrm{C} 2 \mathrm{C}$ interaction is 10.8321. The simulation result from scenario 2 has a better average distance of learning efficiency than scenario 1. The distance is smaller if we include all cost than include CE1 and CE2 only.

We could claim if we can minimize the difference in perception among customers and provider, then we can get the optimum result. Therefore, in our model the assumption cost of mutual learning among customers and provider give impact. Finally, we could claim that 'no interaction' could neither reach a good performance nor efficient way.

It shows the importance customer-to-customer $(\mathrm{C} 2 \mathrm{C})$ interaction and mutual learning is critical in our model. Customer-to-customer $(\mathrm{C} 2 \mathrm{C})$ in the community is powerful when done by customers, i.e., customers not only give information but also recommend about the service provider to the others.

\section{Discussion}

Based on the simulation result, no interaction always shows the worst performance than customer-to-customer $(\mathrm{C} 2 \mathrm{C})$ interaction. Customer-to-customer $(\mathrm{C} 2 \mathrm{C})$ interaction as an individual interaction between customers in the community is powerful when done by customers and when they give information also recommend about the service provider. It is free and we do not waste any money. From service science perspective, we made a mathematical model of value co-creation which based on mutual learning between customers and provider (Novani and Kijima, 2010). Meanwhile, for provider, it is the best way how they promote their business and how to increase their revenue.

The interaction among customers not only in the business but also occur outside even online. These interactions are hard to check, let alone control. The business cannot predict the nature and the outcome may or may not favor the company. If the customers happier than they were before coming to the company or in other words, it will happen if provider take care of customers and provider offer them great service.

By checking the simulation result, we show that communication style gives impact. In our research we show customer-to-customer (C2C) interaction gives impact than 'no interaction'. Moreover, we have already shown mutual learning also gives impact. By mutual learning, customers learn from the others in the service system. It is not only customers learn from the others but also providers learn from customers to create the value. In this research, value is about joint collaboration not only between customers and provider but also among customers itself.

In our research, we model that customer and provider learn and collaborate to create the value, therefore mutual learning between customers and provider give impact. Willingness to communicate and share the internal model among community members are very important in order for these processes to take place. In today's global markets, customer experience has become a key business differentiator, yet delighting customers is not always easy. We conduct agent based simulation by analyzing sensitivity about the importance mutual learning. Customers can choose the interaction style which preferred or what kind of medium they use, then it is a good chance for the provider.

In this research, we focused on agent based model for value co-creation to show the importance customer-to-customer (C2C) interaction, furthermore mutual learning also created. The limitation in this research is only focused only on the positive $\mathrm{C} 2 \mathrm{C}$ interaction which believed as one of the most effective ways to create loyal customers for marketers. At the next step, we will look into more detail on customer-to-customer (C2C) interaction which divides it into $\mathrm{C} 2 \mathrm{C}$ dimensions such as offline (face-to-face) versus online (social media) as appeared in the previous paper (Novani and Kijima, 2012) and negative interaction to show the importance customer-to-customer $(\mathrm{C} 2 \mathrm{C})$ interaction.

\section{References}

Alter, S. (2010). Service systems and service-dominant logic: Partners or distant cousins? Journal on Relationship Marketing, 9(2), 98. http://dx.doi.org/10.1080/15332661003768740

Cova, B., Ford, D., \& Salle, R. (2009). Academic brands and their impact on scientific endeavors: The case of business market research and researchers. Industrial Marketing Management, 38(6), 570-576. http://dx.doi.org/10.1016/j.indmarman.2009.05.005

Lusch, R. F., \& Vargo, S. L. (2006). Service-dominant logic: Reactions, reflections and refinements. Marketing Theory, 6(3), 281. http://dx.doi.org/10.1177/1470593106066781

Lusch, R., \& Vargo, S. (2006). Service-Dominant logic as a foundation for a general theory. The 
Service-dominant Logic of Marketing: Dialog, Debate, And Directions.

Lusch, R., \& Vargo, S. (2008). The service-dominant mindset. Service Science, Management and Engineering Education for the 21st Century, 89-96. http://dx.doi.org/10.1007/978-0-387-76578-5_15

Lusch, R. F., \& Vargo, S. L. (2006). Service-dominant logic as a foundation for a general theory. In Lusch, R. F., \& Vargo, S. L., (Eds.), The service-dominant logic of marketing: Dialog, debate, and directions (pp. 406-420). Armonk, NY: ME Sharpe.

Maglio, P., Vargo, S., Caswell, N., \& Spohrer, J. (2009). The service system is the basic abstraction of service science. Information Systems and E-Business Management, 7(4), 395-406. http://dx.doi.org/10.1007/s10257-008-0105-1

Martin, C. L. (1996). Consumer-to-consumer relationships: satisfaction with the other consumer public behavior. Journal of Consumer Affairs, 30(1), 146-169. http://dx.doi.org/10.1111/j.1745-6606.1996.tb00729.x

Martin, C. L., \& Pranter, C. A. (1989). Compatibility management: Customer-to-customer relationships in service environments. Journal of Service. Marketing, 3(3), 5-15. http://dx.doi.org/10.1108/EUM0000000002488

Parker, C., \& Ward, P. (2000). An analysis of role adoptions and scripts during customer-to-customer $\begin{array}{llll}\text { encounters. } \quad \text { European Journal of } & \text { 341-458. }\end{array}$ http://dx.doi.org/10.1108/03090560010311894

Novani, S., \& Kijima, K. (2010). Value Co-Creation Model of Service Innovation: Symbiotic Hypergame Analysis, Proceedings of the 54th Annual Meeting of the ISSS, Proceedings of the 54th Meeting of the International Society for the Systems Sciences.

Novani, S., \& Kijima, K. (2012). Value Co-Creation by Customer-to-Customer Communication: Social Media and Face-to-Face for Case of Airline Service Selection. Journal of Service Science and Management, 5(1), 101-109. http://dx.doi.org/10.4236/jssm.2012.51013

Novani, S., \& Kijima, K. (2010). Symbiotic hypergame analysis of value co-creation process in service system. 7 th international conference on service systems and service management.

Novani, S., \& Kijima, K. (2011). Service Value Created by Customers' Information Exchange About Provider: Agent Based Simulation Approach. 2011 Annual SRII global conference.

Pranter, C. A., \& Martin, C. L. (1991). Compatibility Management: Roles in Service Performers. The Journal of Services Marketing, 5(2), 43-53. http://dx.doi.org/10.1108/08876049110035530

Putro, U. S., Kijima, K., \& Takahashi, S. (2000). Adaptive Learning of Hypergame Situations by Using Genetic Algorithm. IEEE Transactions on Systems, Man and Cybernetics, 30(5), 562-572. http://dx.doi.org/10.1109/3468.867863

Sheth, J. N., \& Uslay, C. (2007). Implications of the revised definition of marketing from exchange to value creation. Journal of Public Policy and Marketing, 26(2), 302-307. http://dx.doi.org/10.1509/jppm.26.2.302

Thurau-Hennig, T., \& Walsch, G. (2003). Electronic word-of-mouth: motives for and consequences of reading customer articulations on the internet. International Journal of Electronic Commerce, 8(2), 51-74.

Vargo, S., \& Lusch, R. F. (2004). Evolving to a New Dominant Logic for Marketing. Journal of Marketing, 68(1), 1-17. http://dx.doi.org/10.1509/jmkg.68.1.1.24036

Vargo, S. L., \& Lusch, R. F. (2008). From goods to service(s): Divergences and convergences of logics. Industrial Marketing Management, 37(3), 254-259. http://dx.doi.org/10.1016/j.indmarman.2007.07.004

Vargo, S. L., \& Lusch, R. F. (2008). Service-Dominant logic: Continuing the evolution. Journal of the Academy of Marketing Science, 36(1), 1-10. http://dx.doi.org/10.1007/s11747-007-0069-6

Wuyts, Stefan, H. K., Marnik, G., Dekimpe, E. G., \& (Rik) Pieters, F. G. M. (2010). The Connected Customer: The Changing Nature of Consumer and Business Markets. New York: Routledge.

Zeithaml, V. A. (1981). How consumer evaluation processes differ between goods and services. Marketing of Services, 9(1), 25-32. 